Samejima, H. \& Myers, J. (1958). J. gen. Microbiol. 18, 107-117

\title{
On the Heterotrophic Growth of Chlorella pyrenoidosa
}

\author{
By H. SAMEJIMA AND J. MYERS \\ Laboratory of Algal Physiology, University of Texas, Austin, Texas, U.S.A.
}

SUMMARY: Of a large number of possible carbon sources only glucose, galactose, and acetate supported continued growth of Chlorella pyrenoidosa in darkness. Cell synthesis in darkness with nitrate as the nitrogen source proceeded with a carbon assimilation of $45 \%$ for glucose, $37 \%$ for galactose, and $26 \%$ for acetate. The energy efficiency (Rubner coefficient) of cell synthesis from glucose was affected by the nitrogen source and has a maximum value of $58 \%$ with ammonia.

The spectrum of nutritional characteristics found among the algae ranges from obligate autotrophy to obligate heterotrophy. A number of species in the genera Chlorella and Scenedesmus lie near the midpoint of the spectrum in the sense that they shift rapidly and reversibly between growth in darkness on organic substrates and growth in light on carbon dioxide. Ability to utilize organic substrates appears subject to wide variation between species and strains (Algeus, 1946; Bristol Roach, 1927; Fogg, 1953; Killam \& Myers, 1956; Neish, 1951). For example, the Columbia strain of Chlorella vulgaris utilizes glucose, fructose, galactose and four $\beta$-glucosides for growth in darkness (Neish, 1951). In contrast, it has seemed surprising from the more casual observations of this laboratory that the Emerson strain of $C$. pyrenoidosa must be far more limited in its ability to utilize organic carbon sources. The present work examines the utilization of carbon sources by $C$. pyrenoidosa with some observations on two other species. Quantitative data will be presented on growth rates, yields, and efficiencies of substrate utilization for cell synthesis.

\section{METHODS}

The algal species studied included Chlorella pyrenoidosa (Emerson strain), C. ellipsoidea (from Dr H. Tamiya) and Scenedesmus sp. D3 (from Dr H. Gaffron).

The basal medium was a Knop's solution of the following composition (g./l.): 1.25, $\mathrm{KNO}_{3} ; 1 \cdot 25, \mathrm{KH}_{2} \mathrm{PO}_{4} ; 2 \cdot 5, \mathrm{MgSO}_{4} .7 \mathrm{H}_{2} \mathrm{O} ; 0.30, \mathrm{Na}$ citrate; $0 \cdot 004, \mathrm{Fe}_{2}\left(\mathrm{SO}_{4}\right)_{3} ; 0 \cdot 0029, \mathrm{H}_{3} \mathrm{BO}_{3} ; 0 \cdot 0018, \mathrm{MnCl}_{2} \cdot 4 \mathrm{H}_{2} \mathrm{O} ; 0 \cdot 00022, \mathrm{ZnSO}_{4} \cdot 7 \mathrm{H}_{2} \mathrm{O}$; $0.000080, \mathrm{CuSO}_{4} .5 \mathrm{H}_{2} \mathrm{O} ; 0.000018, \mathrm{MoO}_{3}$. The $\mathrm{pH}$ value was adjusted with $\mathbf{K O H}$ to $5 \cdot 6-5 \cdot 8$. Organic substrates at twice final concentration were filtersterilized or autoclaved separately and mixed with an equal volume of autoclaved basal medium of double strength.

Growth rates were measured photometrically in test-tube cultures containing $15 \mathrm{ml}$. medium aerated with $5 \%(\mathrm{v} / \mathrm{v})$ carbon dioxide in air and immersed in water baths thermostated at $25 \pm 0 \cdot 1^{\circ}$. The cultures were enclosed in a dark chamber or illuminated by fluorescent lamps from both sides of the bath. 
Each culture was inoculated with $1.0 \mathrm{ml}$. of an algal suspension grown photosynthetically in basal medium. For Chlorella ellipsoidea and C. pyrenoidosa inocula were taken from a continuous culture apparatus. At intervals the optical density was observed in an Evelyn colorimeter with a $600 \mathrm{~m} \mu$. filter. The logarithm of optical density plotted against time gives a curve (cf. Fig. 1),

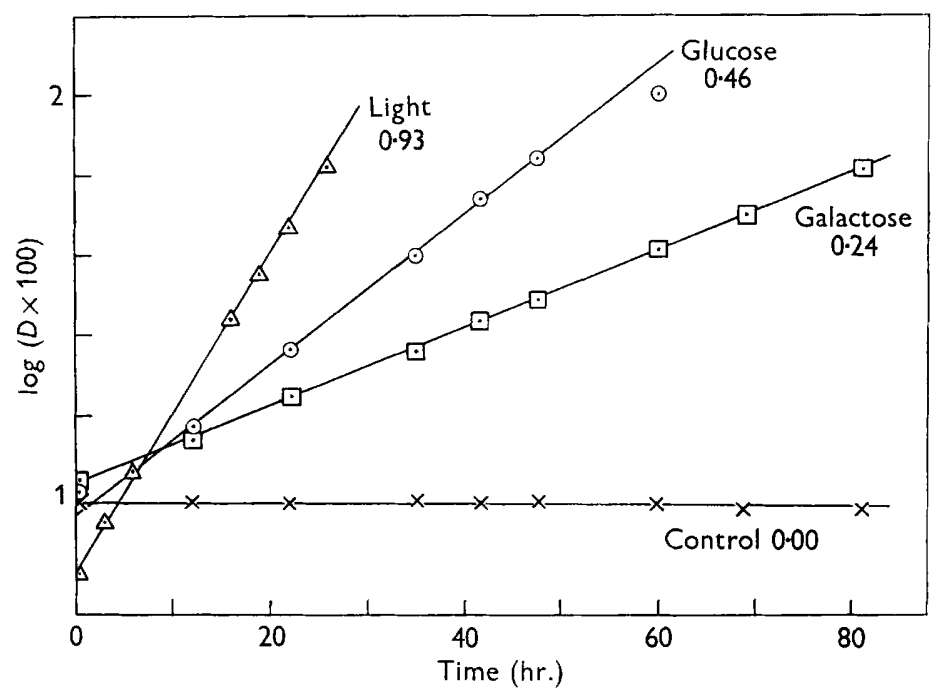

Fig. 1. Growth curves in terms of optical density $(D)$. Chlorella pyrenoidosa at $25^{\circ}$ in basal medium aerated with $5 \%(\mathrm{v} / \mathrm{v}) \mathrm{CO}_{2}$ in air, in light, in darkness (control), and in darkness with addition of $1 \%$ of the substrate indicated. The figures underneath the curves represent values of the specific growth rates.

the slope of which is the specific growth rate. Values of the specific growth rate $k$ will be reported in the convenient dimensions of $\log _{10}$ units/day as for the equation $\log _{10} N / N_{0}=k t$.

Growth yield was determined in cultures grown in $200 \mathrm{ml}$. test tubes in darkness at $25^{\circ}$ and aerated with $5 \%(\mathrm{v} / \mathrm{v})$ carbon dioxide in air. Samples of medium containing known amounts of carbon source were distributed to each of a series of tubes. Organisms for inoculation were washed twice in water with aseptic precautions and $1.0 \mathrm{ml}$. of suspension delivered to each tube. The cultures were harvested at intervals by centrifugation, and the organisms washed thrice in water and dried at $100-110^{\circ}$ to constant weight in tared crucibles. One of the growth curves thus obtained is shown in Fig. 2. Yield of organism was obtained by subtraction of initial weight of organism (inoculum) from the maximum weight of organism developed. For three experiments cells from cultures at maximum yield were prepared by lyophilization for elementary analysis. Lyophilization was chosen since cells dried at 100-110 ${ }^{\circ}$ from a suspension in water gave erratic values for ash content. The elementary analyses reported were obtained from the Biochemical Institute, University of Texas. 


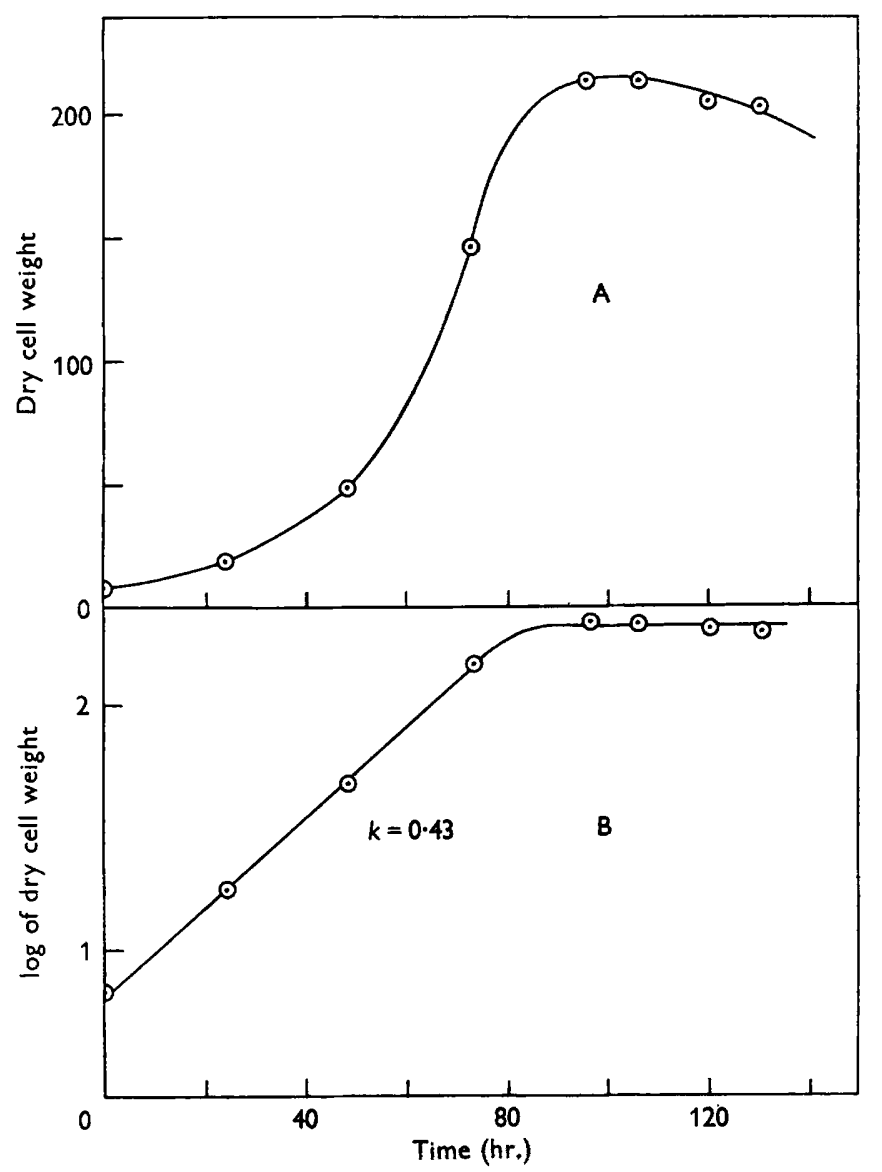

Fig. 2. A growth curve typical of cell yield experiments (A) plotted also on a logarithmic basis (B). The experiment shown provided the eighth horizontal column of data of Table 3.

\section{RESULTS \\ Growth-rate studies}

Sugars and sugar-alcohols in darkness. The following were tested at a concentration of $1 \%(\mathrm{w} / \mathrm{v})$ : arabinose, xylose, ribose, glucose, mannose, galactose, fructose, maltose, sucrose, lactose, cellobiose, glycerol, mannitol, $i$-inositol. Of these only glucose and galactose clearly supported growth of the two Chlorellas. Good growth of Scenedesmus sp. D3 was obtained only on glucose, although slow $(k<0 \cdot 06)$, but continued growth was supported by galactose, mannose, fructose, maltose, sucrose, or lactose. For the Chlorellas xylose, arabinose, fructose, and maltose supported a small amount of growth which persisted only during the first $\mathbf{3 0 - 7 0} \mathrm{hr}$. Two explanations are possible: (1) a small amount of assimilable carbon source occurs in these sugars as an impurity, or (2) these sugars are utilized as long as there exist in the cells some substances required for priming reactions. 
Sugars at different light intensities. It has been observed that very low illumination markedly accelerates growth of Chlorella vulgaris (Emerson strain) on glucose (Killam \& Myers, 1956). Results of a search for the same phenomenon with the present Chlorellas on five sugars is presented in Table 2. Two different light intensities were obtained by filtering the fluorescent illumination through layers of paper. The data of Table 2 may be examined

Table 1. Growth rates of Chlorella pyrenoidosa, C. ellipsoidea and Scenedesmus sp. D3 on various carbon sources

Growth at $25^{\circ}$ in basal medium of initial pH 5.6-5.8 aerated with $5 \%(v / v) \mathrm{Co}_{2}$ in air; values of specific growth rate are expressed in $\log _{10}$ unit/day.

$$
\begin{array}{lll}
\text { C. pyrenoidosa } & \text { C. ellipsoidea Scenedesmus D3 }
\end{array}
$$

In darkness

Single substrate $(\%, w / v)$

Glucose, 1

Galactose, 1

$\mathrm{Na}$ acetate, $0 \cdot 1$

$\mathrm{Na}$ glycolate, $0 \cdot 1$

Glucose $(0.5 \%, w / v)$

+ substrate $(\%, w / v)$

$\mathrm{Na}$ formate, $\mathbf{0} \cdot 1$

$\mathrm{Na}$ acetate, $0 \cdot 1$

Na propionate, $0 \cdot 1$

Na butyrate, $0 \cdot 1$

Basal medium alone

At light-saturation

Basal medium alone
Specific growth rate $\left(\log _{10}\right.$ unit/day)

$\begin{array}{ccc}0.46 & 0.47 & 0.26 \\ 0.24 & 0 \cdot 19 & 0.04 \\ 0.27 & 0.23 & \cdot \\ 0.00 & 0.02 & \cdot \\ & & \\ 0.36 & 0.00 & \\ 0.33 & 0.31 & \cdot \\ 0.00 & 0.00 & \cdot \\ 0.00 & 0.00 & . \\ 0.00 & 0.00 & 0.00 \\ 0.93 & & \\ & 0.87 & 0.65\end{array}$

Table 2. Growth rates of Chlorella pyrenoidosa and C. ellipsoidea on sugars at different light intensities

Growth at $25^{\circ}$ in basal medium $+1 \%(w / v)$ sugar. Values of specific growth rate are expressed in $\log _{10}$ unit/day

Sugar

Chlorella pyrenoidosa

None

Glucose

Galactose

Fructose

Maltose

Sucrose

Light intensity

$\overbrace{\text { Darkness Weak light Medium light }}^{\text {Whe }}$

Specific growth rate $\left(\log _{10}\right.$ unit/day)

Chlorella ellipsoidea

None

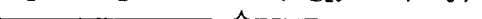

Glucose

Galactose

Fructose

Maltose

0.00

$0 \cdot 01$

0.17

$0 \cdot 46$

0.54

$0 \cdot 64$

$\mathbf{0 \cdot 2 4}$

0.25

$0 \cdot 32$

$0 \cdot 00$

0.05

$0 \cdot 17$

0.00

0.03

$0 \cdot 17$

0.00

0.03

$0 \cdot 16$

Sucrose

0.00

0.02

$0 \cdot 19$

0.47

0.54

$0 \cdot 64$

0.19

$0 \cdot 14$

0.41

$0 \cdot 00$

0.03

0.20

0.00

0.00

0.17

0.00

0.03

0.18 
with the question whether the growth rate on sugar + light is more than the additive effect of sugar and light presented independently. For both strains there are possible small effects of doubtful significance. There is no evidence of any marked increase in assimilation of any of the sugars by light. Nor is there any evidence that a priming effect of light by accumulated photosynthetic products can explain the transient initial growth noted above for fructose and maltose.

Glucose and galactose presented together in darkness. Since in darkness the growth rate on glucose is about $1 / 2$, and on galactose about $1 / 4$, of the lightsaturated growth rate, there is a possibility of additive effects of the two sugars. However, the measured growth rates on glucose and on glucose + galactose were identical. Apparently there is a common rate-limiting reaction saturated by glucose.

Sugar phosphates in darkness. Phosphoglycerate, glucose-1-phosphate, glucose-6-phosphate, fructose phosphate, and fructose-1:6-diphosphate were examined. Except for slight initial and transient effects none of these compounds supported significant growth of either of the two Chlorellas.

Organic acids in darkness. Examination of the organic acids is attended by a technical difficulty. The fatty acids are exceedingly toxic in their undissociated forms. Previous work of this laboratory (1947, unpublished) showed that for Chlorella pyrenoidosa photosynthesis is almost completely inhibited and glucose respiration more than $50 \%$ inhibited by $0.004 \mathrm{M}$ total acetic acid at pH 4.5. At higher $\mathrm{pH}$ values apparent toxicity of total acetic acid concentration decreases, but even at $\mathrm{pH} \quad 6 \cdot 7$ addition of $1 \%(\mathrm{w} / \mathrm{v})$ sodium acetate inhibits growth. The substituted acids with lower $\mathrm{p} K$ values are far less toxic.

The present work was limited to examination of the following substances at $0 \cdot 1 \%(\mathrm{w} / \mathrm{v})$ concentration and $\mathrm{pH} 5 \cdot 6-5 \cdot 7$ : glycine, L-aspartic acid and the sodium salts of formate, acetate, propionate, butyrate, lactate, succinate, $\alpha$-ketoglutarate, pyruvate, malate, glycollate, fumarate, tartrate, malonate, and glutamate. Of these only acetate supported continued and unequivocal growth for both of the Chlorellas. Glycollate supported slight and apparently continued growth of Chlorella ellipsoidea but not of C.pyrenoidosa. The latter result is of interest in view of the observation of Tolbert \& Zill (1956) that small amounts of glycollic acid, as observed with ${ }^{14} \mathrm{C}$ tracer, may be excreted and re-absorbed by $C$. pyrenoidosa during photosynthesis.

Further examination of the acids listed above at $0 \cdot 1 \%(\mathrm{w} / \mathrm{v})$ concentration and with addition of $0.5 \%(\mathrm{w} / \mathrm{v})$ glucose yielded the following results as compared to glucose alone: (1) slight depression by acetate and slight or complete suppression by formate, propionate or butyrate (cf. Table 1); (2) no significant effects of other acids.

Possible growth factors. The fact that all growth rates observed in darkness were lower than the light-saturated rates leaves the possibility of a growthfactor stimulation of heterotrophic growth. Such a stimulation was sought but not found by independent additions of $0.1 \%(w / v)$ yeast, liver, and meatextracts and Casamino acids to $1 \%$ glucose. 


\section{Cell-yield studies}

A second criterion of growth on organic substrates can be put in terms of the maximum yield of cell material/unit quantity of substrate. It may be expressed as in studies of mould metabolism (Foster, 1949) by the economic coefficient (weight of organism produced $\times 100$ /weight of substrate consumed). Or, with knowledge of the composition of the cells produced, it may be expressed as $\%$ carbon assimilated (cell carbon $\times 100 /$ substrate carbon consumed). It is assumed that maximum yield of cells in all cases corresponds to practically complete consumption of substrate. Further, no cognizance is taken of any extracellular organic products, although these may be expected to be small (Myers \& Johnston, 1949).

As a further variable it appeared desirable to examine effects of nitrogen source on efficiency of glucose assimilation. To this end either $0 \cdot 20 \%(\mathrm{w} / \mathrm{v})$ filter-sterilized urea or $0.15 \%(\mathrm{w} / \mathrm{v}) \mathrm{NH}_{4} \mathrm{H}_{2} \mathrm{PO}_{4}+0.125 \%$ (w/v) tris (buffer) 2-amino-2-hydroxymethylpropane-1:3-diol were substituted for $\mathrm{KNO}_{3}$ in the basal medium. Use of tris (buffer) as additional buffer is required to prevent decrease in $\mathrm{pH}$ to toxic values during assimilation of ammonia.

Table 3. Yields of Chlorella pyrenoidosa and C. ellipsoidea grown on various carbon and nitrogen sources

\begin{tabular}{|c|c|c|c|c|c|c|c|c|c|}
\hline \multirow[b]{2}{*}{$\begin{array}{l}\text { Cảrbon } \\
\text { Source }\end{array}$} & \multirow[b]{2}{*}{$\begin{array}{l}\text { Nitrogen } \\
\text { source }\end{array}$} & \multirow[b]{2}{*}{$\begin{array}{l}\text { Volume of } \\
\text { culture } \\
\text { (ml.) }\end{array}$} & \multirow[b]{2}{*}{$\begin{array}{c}\text { Amount } \\
\text { C source } \\
\text { (mg.) }\end{array}$} & \multicolumn{4}{|c|}{ Organisms } & \multirow{2}{*}{$\begin{array}{c}\text { Econo- } \\
\text { mic } \\
\text { coeffi- } \\
\text { cient } \\
(\%)\end{array}$} & \multirow[b]{2}{*}{$\begin{array}{c}\text { Carbon } \dagger \\
\text { assimi- } \\
\text { lation } \\
(\%)\end{array}$} \\
\hline & & & & $\begin{array}{l}\text { Initial } \\
\text { (mg.) }\end{array}$ & $\begin{array}{l}\text { Max. } \\
\text { (mg.) }\end{array}$ & $\begin{array}{l}\text { Yield } \\
\text { (mg.) }\end{array}$ & $\begin{array}{c}k^{*} \\
\left(\log _{10} /\right. \\
\text { day) }\end{array}$ & & \\
\hline \multicolumn{10}{|c|}{ Chlorella pyrenoidosa } \\
\hline Glucose & Nitrate & $\begin{array}{r}100 \\
50 \\
50\end{array}$ & $\begin{array}{l}500 \\
250 \\
250\end{array}$ & $\begin{array}{l}6 \cdot 5 \\
4.3 \\
1.5\end{array}$ & $\begin{array}{c}186 \cdot 6 \\
97 \cdot 0 \S \\
95 \cdot 1\end{array}$ & $\begin{array}{r}180 \cdot 1 \\
92 \cdot 7 \\
93 \cdot 6\end{array}$ & $\begin{array}{l}0.44 \\
0.45 \\
0.43\end{array}$ & $\begin{array}{l}36 \\
37 \\
37\end{array}$ & $\begin{array}{l}43 \\
45 \\
45\end{array}$ \\
\hline Galactose & Nitrate & $\mathbf{5 0}$ & 250 & $4 \cdot 0$ & $81 \cdot 3$ & $\mathbf{7 7 \cdot 3}$ & $0 \cdot 2$ & 31 & 37 \\
\hline Na acetate & Nitrate & 50 & 100 & $3 \cdot 8$ & $13 \cdot 5$ & $9 \cdot 7$ & $0 \cdot 16$ & 10 & 26 \\
\hline \multirow[t]{2}{*}{ Glucose } & Ammonia & $\begin{array}{l}15 \\
50\end{array}$ & $\begin{array}{r}75 \\
250\end{array}$ & $\begin{array}{l}2 \cdot 7 \\
2 \cdot 2\end{array}$ & $\begin{array}{c}33 \cdot 5 \\
108 \cdot 7 \S\end{array}$ & $\begin{array}{r}30 \cdot 8 \\
106 \cdot 5\end{array}$ & $\begin{array}{l}0.4 \\
0.5\end{array}$ & $\begin{array}{l}41 \\
43\end{array}$ & $\begin{array}{l}48 \\
51\end{array}$ \\
\hline & Urea & $\begin{array}{r}100 \\
50\end{array}$ & $\begin{array}{l}500 \\
\mathbf{2 5 0}\end{array}$ & $\begin{array}{l}6 \cdot 6 \\
1.5\end{array}$ & $\begin{array}{l}213 \cdot 9 \\
104 \cdot 4 \S\end{array}$ & $\begin{array}{l}207 \cdot 3 \\
102 \cdot 9\end{array}$ & $\begin{array}{l}0 \cdot 43 \\
0 \cdot 47\end{array}$ & $\begin{array}{l}41 \\
41\end{array}$ & $\begin{array}{l}50 \\
49\end{array}$ \\
\hline \multirow[t]{2}{*}{$\begin{array}{l}\text { C. ellipsoidea } \\
\text { Glucose }\end{array}$} & Nitrate & 50 & 250 & $\mathbf{3 \cdot 6}$ & $112 \cdot 8$ & $109 \cdot 2$ & 0.5 & 44 & 53 \\
\hline & Urea & 50 & 250 & $7 \cdot 0$ & $129 \cdot 9$ & $122 \cdot 9$ & $0 \cdot 40$ & 49 & $\mathbf{5 9}$ \\
\hline
\end{tabular}

* Specific growth rate; varying degrees of reliability reflect differences in number of samples taken during exponential period of growth.

$\dagger$ Approximate: calculated for average cell product of $48 \%$ carbon.

$\S$ Duplicate lyophilized samples were used for the cell analyses reported in Table 4.

The pertinent data are presented in Table 3. The values of specific growth rate cited have different degrees of reliability depending upon the number of sampling points on which they are based. Internal comparisons can be made in terms of the economic coefficient, or in equivalent terms of approximate $\%$ carbon assimilated. 
Glucose versus galactose. It is difficult to visualize a model which will explain why galactose should be assimilated less completely than glucose. However, it will be noted that for galactose the specific growth rate is much lower. Consumption of a given quantity of substrate requires a longer time period for galactose, attended by a greater fractional contribution to basal or maintenance metabolism. Simplification of the growth curve such as Fig. $2 \mathrm{~A}$ to an exponential curve breaking sharply at the maximum, the integrated area under the curve $\left(e^{k^{\prime} t}-1\right) N_{0} / k^{\prime}$ gives the mg.-hr. of cells required to consume the substrate. For consumption of $100 \mathrm{mg}$. substrate carbon the above calculation yields $2230 \mathrm{mg}$.-hr. for glucose and $4700 \mathrm{mg}$.-hr. for galactose. (Actually the figure of $\mathrm{mg}$-hr. for galactose is higher than calculated since the terminal growth rate did not break sharply but fell slowly in approach to zero.) It appears that a greater contribution to maintenance metabolism can explain the less complete assimilation of galactose. It follows as a general principle that substrates which support lower growth rates may show lower efficiency of assimilation because of necessarily greater contribution to maintenance metabolism.

Glucose versus acetate. Experiments were limited to low initial quantities of acetate because of toxic effects at higher concentrations. The markedly less complete assimilation of acetate is to be expected for reasons besides that presented above for galactose; a less complete assimilation of acetate to starch has been found in manometric studies of oxidative assimilation in starved cells of Chlorella pyrenoidosa (Myers, 1947).

Chlorella pyrenoidosa versus $\mathrm{C}$. ellipsoidea. Comparison of the two species shows a clearly more complete assimilation of glucose by $C$. ellipsoidea than by C. pyrenoidosa.

Effect of nitrogen source. As compared with nitrate, both ammonia and urea allowed more complete assimilation of carbon from glucose. This was to be expected as a consequence of the energy demand for nitrate reduction; it is explored further in terms of the more complete data on cell analysis presented below.

Effect of added substrates. The possible utilization of other substrates during glucose assimilation may be tested by adding the substrate and examining whether there is any increase in carbon assimilation as calculated for the glucose carbon. This was done with Chlorella pyrenoidosa for fructose, maltose, sucrose and glycollic acids by additions of $0.5 \%(\mathrm{w} / \mathrm{v})$ of each substrate to $0.5 \%(\mathrm{w} / \mathrm{v})$ glucose. No increase in the economic coefficient for glucose utilization was observed in any case. The result provides convincing evidence that these substances are not utilized even during glucose assimilation.

\section{Efficiency of cell synthesis}

Efficiencies of conversion and comparison of effects of nitrogen source can be obtained from elementary analyses on three of the samples noted in Table 3; the salient results are presented in Table 4 . From the elementary analyses, taking oxygen by difference and calculating to an ash-free organic substance basis, the cell compositions may be expressed as molecular formulae which 
Table 4. Cellular composition and derived values for Chlorella pyrenoidosa grown in darkness on glucose

\begin{tabular}{|c|c|c|c|c|c|c|c|c|c|c|}
\hline \multirow{3}{*}{$\begin{array}{l}\text { Nitrogen } \\
\text { source }\end{array}$} & \multicolumn{8}{|c|}{ 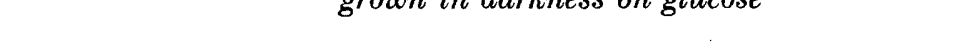 } & \multicolumn{2}{|c|}{ Efficiencies (\%) } \\
\hline & \multicolumn{4}{|c|}{ Elementary analysis (\%) } & \multirow{2}{*}{$\begin{array}{c}\text { Ash-free } \\
\text { unit formula }\end{array}$} & \multirow{2}{*}{$\begin{array}{c}\text { Formula } \\
\text { weight }\end{array}$} & \multirow{2}{*}{$\begin{array}{c}\text { Carbon } \\
\text { recovery } \\
(\%)\end{array}$} & \multirow{2}{*}{$\begin{array}{c}\Delta \mathbf{H}_{\text {comb. }} \\
\text { (kcal./ } \\
\text { mole) }\end{array}$} & \multirow{2}{*}{$\begin{array}{c}\text { Rubner } \\
\text { coeffi- } \\
\text { cient }\end{array}$} & \multirow{2}{*}{$\begin{array}{c}\text { correction } \\
\quad \text { for } \\
\mathbf{N} \text { source }\end{array}$} \\
\hline & $C$ & $H$ & $N$ & Ash & & & & & & \\
\hline Nitrate & $48 \cdot 04$ & $7 \cdot 06$ & $8 \cdot 39$ & $4 \cdot 56$ & $\mathrm{C}_{6 \cdot 68} \mathrm{H}_{11 \cdot 69} \mathrm{O}_{3 \cdot 34} \mathrm{~N}$ & $159 \cdot 3$ & $44 \cdot 7$ & 848 & $50 \cdot 6$ & $56 \cdot 4$ \\
\hline Ammonia & $49 \cdot 13$ & $7 \cdot 12$ & $6 \cdot 41$ & $5 \cdot 05$ & & $207 \cdot 4$ & $51 \cdot 4$ & 1136 & $58 \cdot 2$ & $58 \cdot 2$ \\
\hline Urea & $47 \cdot 93$ & $7 \cdot 24$ & $7 \cdot 46$ & $6 \cdot 43$ & $\mathrm{C}_{7.51} \mathrm{H}_{13 \cdot 60} \mathrm{O}_{3 \cdot 63} \mathrm{~N}$ & $175 \cdot 8$ & $49 \cdot 5$ & 971 & $57 \cdot 0$ & $57 \cdot 2$ \\
\hline
\end{tabular}

here are reduced arbitrarily to unit nitrogen. If it be assumed that the metabolic carbon products are only cells and carbon dioxide, an assumption correct to better than $90 \%$ (Myers \& Johnston, 1949), the following balanced equations may be written to express over-all metabolism.

On nitrate:

$\mathrm{HNO}_{3}+2 \cdot 49 \mathrm{C}_{6} \mathrm{H}_{12} \mathrm{O}_{6}+5 \cdot 78 \mathrm{O}_{2} \rightarrow \mathrm{C}_{6 \cdot 68} \mathrm{H}_{11 \cdot 69} \mathrm{O}_{3 \cdot 34} \mathrm{~N}+8 \cdot 28 \mathrm{CO}_{2}+9 \cdot 60 \mathrm{H}_{2} \mathrm{O}$.

On ammonia:

$\mathrm{NH}_{4} \mathrm{OH}+2 \cdot 90 \mathrm{C}_{6} \mathrm{H}_{12} \mathrm{O}_{6}+7 \cdot 28 \mathrm{O}_{2} \rightarrow \mathrm{C}_{8 \cdot 94} \mathrm{H}_{15 \cdot 56} \mathrm{O}_{4 \cdot 41} \mathrm{~N}+8 \cdot 46 \mathrm{CO}_{2}+11 \cdot 62 \mathrm{H}_{2} \mathrm{O}$.

On urea:

$$
\begin{array}{r}
0 \cdot 5 \mathrm{~N}_{2} \mathrm{H}_{4} \mathrm{CO}+2 \cdot 53 \mathrm{C}_{6} \mathrm{H}_{12} \mathrm{O}_{6}+6 \cdot 83 \mathrm{O}_{2} \rightarrow \mathrm{C}_{7 \cdot 51} \mathrm{H}_{13 \cdot 60} \mathrm{O}_{3 \cdot 63} \mathrm{~N} \\
+8 \cdot 16 \mathrm{CO}_{2}+9 \cdot 38 \mathrm{H}_{2} \mathrm{O} .
\end{array}
$$

The R.Q. values predicted from equations (1) and (2) check reasonably the values obtained manometrically (Cramer \& Myers, 1948).

The heats of combustion of the cells produced may be obtained by determining the number of moles of oxygen required for combustion to $\mathrm{CO}_{2}, \mathrm{H}_{2} \mathrm{O}$ and $\mathrm{N}_{2}$ and taking some figure as the calorie equivalent for one mole of oxygen. The latter figure carries uncertainty within the range $103-113 \mathrm{kcal} . / \mathrm{mole}$. In calculations of photosynthetic efficiency a value of $112 \mathrm{kcal} . / \mathrm{mole}$ is properly chosen since the product is assumed to be carbohydrate. However, for production of total cell material the product is only partly carbohydrate. The problem was examined by Kok (1952) who obtained both calorimetric measurements and cell analyses on cells of a Chlorella grown photosynthetically. Unfortunately, the results were obtained upon parallel samples which differed in ash content. Kok chose to ignore the differences in ash content and estimated an equivalent of $112 \mathrm{kcal} . /$ mole $\mathrm{O}_{2}$. However, when Kok's data are calculated to an ash-free basis and the calorimetric contribution of the ash fraction is considered negligible, then the equivalent becomes $107 \mathrm{kcal} . /$ mole $\mathrm{O}_{2}$.

An independent means of calculating a calorie equivalent for oxygen is provided by the data of Kharasch (1929). Cited values of heat of combustion/ mole for various organic compounds may be divided by the computed mole $\mathrm{O}_{2} /$ mole, required for combustion. For example, the $673 \mathrm{kcal} . / \mathrm{mole}$ heat of combustion of glucose divided by 6 mole $\mathrm{O}_{2} /$ mole gives a calorie equivalent of $112.2 \mathrm{kcal} . / \mathrm{mole} \mathrm{O}_{2}$. For the carbohydrates glucose, sucrose, starch and glycogen the equivalents are in the range $112-113 \mathrm{kcal} . / \mathrm{mole} \mathrm{O}_{2}$. For the lipids glyceryl-trilaurate, palmitic acid, and stearic acid, the equivalents 
range from 104 to $105 \mathrm{kcal} . / \mathrm{mole} \mathrm{O}_{2}$. For the amino acids and peptides aspartic, glutamic, glycine, leucine, phenylalanine, tyrosine, glycylglycine and triglycylglycine, the equivalents range from 103 to $105 \mathrm{kcal} . / \mathrm{mole} \mathrm{O}_{2}$. Using the procedure of Spoehr \& Milner (1949), the average composition of our cells is calculated as $49 \%(\mathrm{w} / \mathrm{w})$ protein, $36 \%(\mathrm{w} / \mathrm{w})$ carbohydrate, and $15 \%(\mathrm{w} / \mathrm{w})$ lipid. From the corresponding oxygen equivalents of protein 104, carbohydrate 112.5 , and lipid $104.5 \mathrm{kcal} . / \mathrm{mole} \mathrm{O}_{2}$, respectively, the weighted average for our cells becomes $107 \mathrm{kcal} . / \mathrm{mole} \mathrm{O}_{2}$ which is taken for calculation of the heats of combustion shown in Table 4.

Efficiencies of metabolic conversions have been variously calculated depending upon the premises and intent of the calculation (cf. Burk, 1931; Winzler \& Baumberger, 1938). As a starting-point we adopt the classical Rubner coefficient (cf. Foster, 1949). Output work performed is taken as the energy stored in the cells produced, in terms of their heat of combustion. Input energy expended is taken as the heat of combustion of the substrate consumed. For example, the efficiency for equation (1) is $848 /(2 \cdot 49 \times 673)=$ 0.506. Calculated values are listed in Table 4 . It will be noted that the efficiency so obtained for cell synthesis from nitrate is significantly lower than that obtained for similar synthesis from ammonia. However, it is clear that additional work is required for reduction of nitrate and that this should be reckoned as part of the output work performed. If it be assumed that cell synthesis starts from nitrogen in a form energetically equivalent to $\mathrm{NH}_{3}$, then equation (1) includes work done in the reaction

$$
\mathrm{HNO}_{3} \text { (aq.) }+2 \mathrm{H}_{2} \mathrm{O}(\mathrm{l}) \rightarrow \mathrm{NH}_{4} \mathrm{OH} \text { (aq.) }+2 \mathrm{O}_{2}, \quad \Delta \mathrm{H}=+98 \cdot 4,
$$

and equation (3) includes the work done in the reaction

$$
0 \cdot 5 \mathrm{~N}_{2} \mathrm{H}_{4} \mathrm{CO} \text { (aq.) }+1 \cdot 5 \mathrm{H}_{2} \mathrm{O}(\mathrm{l}) \rightarrow \mathrm{NH}_{4} \mathrm{OH} \text { (aq.) }+0 \cdot 5 \mathrm{CO}_{2} \text { (aq.) }, \quad \Delta \mathrm{H}=+3 \cdot 6 \text {. }
$$

For example, the corrected efficiency for equation (1) becomes $(848+98)$ / $(2 \cdot 49 \times 673)=0.564$. Efficiency values of Table 4 thus corrected are not significantly different for the different nitrogen sources, although exact identity would imply $100 \%$ efficiency for nitrate reduction.

\section{DISCUSSION}

From the accumulated data on heterotrophic growth of Chlorella pyrenoidosa the nutritional pattern becomes evident. Its cellular synthesis proceeds with high efficiency but only from a very limited number of substrates. Lack of versatility in the use of organic substrates appears to be a result of permeability restrictions. Sucrose, which will not serve as a carbon source for growth, has been identified as an intracellular component (Milner, 1948). Likewise many of the other organic compounds which fail to support growth have been identified as intermediary metabolites by tracer studies (Calvin $e t$ al. 1951).

The maximum rate of cell synthesis provided by light saturated photosynthesis is not increased by addition of glucose (Killam \& Myers, 1956). At low light intensities the rates supported by photosynthesis and glucose assimilation become approximately additive. However, the rate supported by 
glucose in darkness is not augmented by addition of the other utilizable substrates galactose and acetate. A simple hypothesis will encompass these observations: there is a common reaction in cell synthesis from all three substrates which is rate-saturated during glucose assimilation; in photosynthesis this reaction is by-passed by an alternative pathway or is not required.

It is instructive to compare the $58 \%$ efficiency of total cell synthesis from glucose with the efficiency observed for the simpler synthesis of storage carbohydrate alone. The latter has been measured manometrically in starved cells at energy efficiencies which calculate to 83 and $88 \%$ as reported for Chlorella pryenoidosa (Myers, 1947) and C. vulgaris (Syrett, 1951). Further extension may be made to a comparison of the efficiencies of heterotrophic and autotrophic metabolism. For total cell synthesis from carbon dioxide in light an approximate efficiency of $20 \pm 2 \%$ may be taken from the data of Kok (1952) and Oorschot (1955); slightly lower values are being obtained currently in our laboratory. For carbohydrate synthesis from carbon dioxide (photosynthesis) there is a wide scatter of efficiency values corresponding to quantum yields ranging from about $1 / 4$ to $1 / 10$ (Rabinowitch, 1951). A quantum yield of $1 / 8$, observed at $6800 \AA$. where the quantum energy is $42 \mathrm{kcal} /$ Einstein, would correspond to a thermodynamic efficiency of $33 \%$. The last figure cannot be compared rigidly with the other three, not only because of uncertainty as to its exact value, but also because its determination includes correction for respiration or maintenance metabolism not applied in the other cases. However uncertain the comparison may be as applied to photosynthetic efficiency, an important requirement is clearly demonstrated: if photosynthesis is taken to represent synthesis of carbohydrate alone, then its efficiency must be determined under conditions which rigidly preclude other cellular syntheses.

The work described was aided by a Fulbright Fellowship to the senior author and by a grant from the Rockefeller Foundation.

\section{REFERENCES}

Algeus, S. (1946). Untersuchungen über die Ernährungsphysiologie der Chlorophyceen. Bot. Notiser, 129.

Bristol RoAch, B. M. (1927). On the carbon nutrition of some algae isolated from soil. Ann. Bot., Lond. 41, 509.

BURK, D. (1931). The reversibility of coupled reactions in biological systems and the second law of thermodynamics. J. phys. Chem. 35, 432.

Calvin, M., Bassham, J. A., Benson, A. A., Lynch, V. H., Quellet, C., Schou, L., Stepka, W. \& Tolbert, N. E. (1951). Carbon dioxide assimilation in plants. Symp. Soc. exp. Biol. 5, 284.

Cramer, M. \& Myers, J. (1948). Nitrate reduction and assimilation in Chlorella. J. gen. Physiol. $32,93$.

Fogg, G. E. (1953). The Metabolism of Algae. London: Methuen and Co.

Foster, J. W. (1949). Chemical Activities of the Fungi. New York: Academic Press.

Kharasch, M. S. (1929). Heats of combustion of organic compounds. Bur. Stand. J. Res., Wash. 2, 359.

Killam, A. \& Myers, J. (1956). A special effect of light on the growth of Chlorella vulgaris. Amer. J. Bot. 43, 569. 
KoK, B. (1952). On the efficiency of Chlorella growth. Acta Bot. Neerl. 1, 445.

Mrlner, H. W. (1948). The fatty acids of Chlorella. J. biol. Chem. 176, 813.

Myers, J. (1947). Oxidative assimilation in relation to photosynthesis in Chlorella. J. gen. Physiol. 30, 217.

Myers, J. \& Johnston, J. A. (1949). Carbon and nitrogen balance of Chlorella during growth. Plant Physiol. 24, 111.

NeIsi, A. C. (1951). Carbohydrate nutrition of Chlorella vulgaris. Canad. J. Bot. $29,68$.

Oonschot, J. L. P. (1955). Conversion of light energy in algal culture. Meded. LandbHoogesch., Wageningen, 55, 225.

Rabinowitch, E. I. (1951). Photosynthesis, vol. II, part 1. New York: Interscience Publishers.

Spoenr, H. A. \& Milner, H. W. (1949). The chemical composition of Chlorella; effect of environmental conditions. Plant Physiol. 24, 120.

Syrett, P. J. (1951). The effect of cyanide on the respiration and oxidative assimilation of glucose by Chlorella vulgaris. Ann. Bot., Lond. 15, 473.

Tolbert, N. E. \& Zilı, L. P. (1956). Excretion of glycolic acid during photosynthesis. J. biol. Chem. 222, 895.

Winzler, R. J. \& Baumberger, J. P. (1938). The degradation of energy in the metabolism of yeast cells. J. cell. comp. Physiol. 12, 183.

(Received 24, July 1957) 